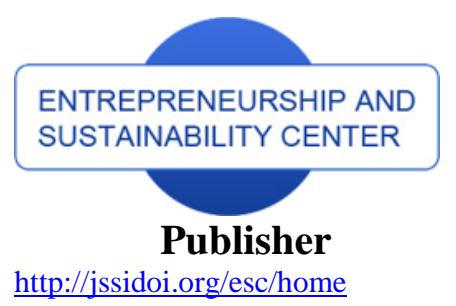

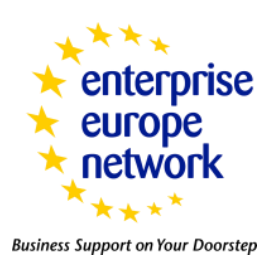

CASPA

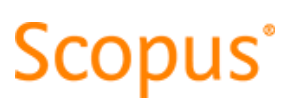

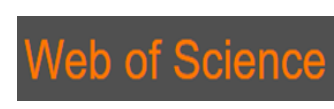

1) Clarivate

Analytics

\title{
GOVERNANCE MECHANISMS AND COLLABORATIVE VALUE CREATION IN CROSS- SECTOR PARTNERSHIPS: CASE OF NGO AND BUSINESS
}

\author{
Jurgita Joniškienė ${ }^{1}$, Diana Šaparnienè ${ }^{2}$, Vita Juknevičienė ${ }^{3}$, Tadas Limba ${ }^{4}$, Iveta Reinholde 5 \\ 1,3 Šiauliai University, P. Višinskio str. 25, Šiauliai, Lithuania \\ ${ }^{2,5}$ University of Latvia, Lauvas str. 4, Riga, Latvia \\ ${ }^{2}$ Klaipeda University, Herkaus Manto str. 84, Klaipéda, Lithuania \\ ${ }^{4}$ Mykolas Romeris University, Ateities str. 20, Vilnius, Lithuania \\ E-mails: ${ }^{1}$ jurgita.joniskiene@su.lt $;{ }^{2}$ diana.saparniene@gmail.com $;{ }^{3}$ vita.jukneviciene@su.lt $;{ }^{4}$ tlimba@mruni.eu; \\ 5iveta.reinholde@lu.lv
}

Received 15 March 2020; accepted 28 June 2020; published 30 September 2020

\begin{abstract}
The article analyses aspects of the cross-sector partnership of NGO and business actualizing the context of the governance dimension and collaborative value creation. The theoretical part of this article revealed the formal (contractual) and informal (relational) governance mechanisms, which influence the behaviour of partners in the cross-sector partnership. Moreover, the research presented organizational and partnership perspectives of the governance in cross-sector partnerships. The case study strategy was applied to conduct empirical research in Lithuania. It was found out that value creation based on collaboration in cross-sector partnership is influenced by partnership context that consists of macro and mezzo stimulating and limiting factors, characteristics of NGO and business organization, selection of a proper partner as well as formal and informal mechanisms of partnership governance.
\end{abstract}

Keywords: cross-sector partnership; governance mechanisms; collaborative (collaboration-based) value creation; contractual and relational mechanisms

Reference to this paper should be made as follows: Joniškienè, J., Šaparnienė, D., Juknevičienė, V., Limba, T., Reinholde, I. 2020. Governance mechanisms and collaborative value creation in cross-sector partnerships: case of NGO and business. Entrepreneurship and Sustainability Issues, 8(1), 1012-1028. http://doi.org/10.9770/jesi.2020.8.1(68)

JEL Classifications: O35, L31, M14

\section{Introduction}

The development of the open market, intensive flows of information and ideas, the communication in real time, the information diffusion via social networks, intensive social changes and the process of globalization, inherently intractable and open-ended challenges such as global warming, poor access to water, pandemics encourage governmental institutions, business and non-governmental organizations to look for new mechanisms of interactions (Dentoni et al. 2016; Yaziji, Doh 2009; Clarke, Fuller 2010). With growing awareness to dense environmental and social issues, meeting economic and technological challenges, public sector, business and 


\section{ENTREPRENEURSHIP AND SUSTAINABILITY ISSUES}

ISSN 2345-0282 (online) http://jssidoi.org/jesi/ 2020 Volume 8 Number 1 (September) http://doi.org/10.9770/jesi.2020.8.1(68)

NGO increasingly combine their resources in order to create greater social value and responsibility for society, to develop new innovative solutions. Cross-sector partnership is seen as a distinct impact on social welfare over recent decades (Van Tulder et al. 2016; Schuster, Holtbrügge 2014), as the main paradigm of collaboration in 21st century and one of essential strategic tools for global organizations (Branzei, Le Ber 2014; Maucuer, Renaud 2019). A cross-sector partnership is defined as "a cross-sector project designed to address social issues and the reasons for involving partners on an ongoing basis" (Selsky, Parker 2005, pp. 850). At the same time specifics of the activity of different sectors makes this collaboration as the complicated process (Selsky, Parker 2005, 2010; Rivera-Santos et al. 2011; Le Pennec, Raufflet 2018).

Partnership of business organizations and NGOs has been developed intensively in recent decade as a possibility for business organizations to create more active and innovative policy towards corporative social responsibility. Although NGO and business organization are not typical partners and this partnership may be complicated to implement, the tangible results of such a partnership are beginning to emerge. The involvement of NGOs in the cross-sector partnership provides them several advantages. First at all, they learn important skills and professionalism (Herlin 2015). NGOs, in collaboration with business organizations, gain the status of trustworthy organizations from the point of view of other stakeholders (Wymer, Samu 2009; Getha-Taylor 2012). Secondly, in the collaboration with business, NGOs gain more financial resources, which can be invested in relevant social projects (Seitanidi 2010). The non-materially motivated NGO leadership can effectively mobilize the community and identify low-cost solutions (Bano 2019). It can be stated that cross-sector partnerships can be seen as a means of strengthening the legitimacy of NGOs Cross-sector partnerships as an innovative source of social innovation and value, ensure the implementation of corporate social responsibility and allow NGOs to increase their capacity to solve various social problems (Le Ber, Branzei 2010; Demir, Budur 2019). It is assumed that organizations from different sectors benefit from synergy effects by pooling their resources, and at the same time they can address social issues that cannot be solved by working alone (Lee 2011). The increase of corporate social responsibility in the private sector encourages business organizations to work with NGOs to gain a positive reputation, thus partly taking responsibility for social problems (Seitanidi 2008). Thus, the popularity of crosssector partnerships (between NGOs and business organizations) is constantly growing (Jamali, Keshishian 2009), leading to an increase of the number of organizations involved in partnerships. Business organizations are increasingly looking for partners with whom they can collaborate effectively because of gaining the competitive advantage (Stejskal et al. 2016). Cross-sector partnerships are one of the most complex ways which is used by business organizations to implement the corporate social responsibility (Seitanidi, Ryan, 2007; Van Tulder, Keen, 2018). Combining different competencies and resources of organizations is a key factor helping to solve complex, large-scale issues that individual organizations are unable to address (Austin 2010; Selsky, Parker 2005). NGOs and business organizations may gain the competitive advantage and create the value together seeking for common aims in the cross-sector partnerships (Teegen et al. 2004; Porter, Kramer 2011; Southby, Gamsu 2018).

Austin and Seitanidi (2012) conceptualize the collaborative value as transitory and enduring benefits relative to other costs which are generated by organizations, individuals, and society because of the interaction with partner organizations. Even the value creation is considered as one of main motives for the cross-sector partnerships, it is not created in every case (Bryson et al. 2006). NGOs and business organizations involve in such partnerships not only because of altruistic purposes, but for instrumental aims such as gaining the benefit, retrieving the recognition, the implementation of corporate social responsibility, etc. The creation of the collaborative value occurs in various forms (Seitanidi, Crane 2009; Sakarya et al. 2012; Hankammer, Kleer 2018; Chesbrough et al. 2018; Sroka, Szántó 2018) such as the usage of core competencies, resource transfer, knowledge exchange and access to new knowledge and networks, increased financial and technological resources, possibility to create and try innovative solutions, improved legitimacy, brand recognition, reputation, perception as a reliable partner, relationships with stakeholders, all of which can contribute to the increase of competitive advantage. However, the process of collaborative value creation needs the appropriate governance mechanisms too. 


\section{ENTREPRENEURSHIP AND SUSTAINABILITY ISSUES}

ISSN 2345-0282 (online) http://jssidoi.org/jesi/ 2020 Volume 8 Number 1 (September) http://doi.org/10.9770/jesi.2020.8.1(68)

Over the last two decades, the cross-sector partnership is analyzed in many scientific researches (Seitanidi 2010; Le Pennec, Raufflet 2018), however, responsibilities of the governance still remains not revealed and are named as "the black box of the governance of collaboration practice" (Kelman et al. 2013). Governance of cross-sector partnerships is very complicated, as the partnership is implemented by various levels, forms, and mechanisms (Clarke, Fuller 2010). Manifestations of the collaborative value in cross-sector partnerships depend not only on the context of the partnership, characteristics of the organization, managerial skills, but also on the application of formal and informal mechanisms of governance. However, there is still a lack of researches that integrate and highlight mechanisms for governing the implementation of cross-sector partnerships in the context of business and NGOs.

The main problematic question of the research is: what are governance mechanisms used for the collaborative value creation in cross sector partnerships in a case of the interaction of NGOs and business organizations. This article reveals practices of the cross-sector partnership's governance, enabling the collaborative value creation in the context of partnerships of NGOs and business organizations. In such a context the governance of cross-sector partnership is analyzed through two dimensions - at the levels organizations and partnerships including two interrelated aspects - formal (contractual) and informal (relational) governance mechanisms. It is assumed that used governance mechanisms have the influence on the behavior of the partner in the cross-sector partnership.

The aim of the empirical research is to disclosure of governance mechanisms of the collaborative value creation in the cross-sector partnership, focusing on the case of NGO and business partnership. In the context of crosssector partnership, the article interprets the collaboration as a process in which organizations interact with each other to create the collaborative value revealing internal mechanisms of collaboration and the decision-making process. In this article cross-sector partnership is defined as the context in which the cross-sector collaboration proceeds. Processes of cross-sector partnership's governance are analyzed using different theoretical approaches such as Resource dependence theory, Collaborative Governance, Relational Governance and Inter-Organizational relations. Scientific methods such as semi-structured interviews, systematization and interpretation have been used for this research.

\section{Theoretical background of the research}

The partnership is considered as the meaningful and widespread cross-sectoral interaction, initiatives to ensure consistent, innovative, sustainable development, which enables partners to solve complex economic and social problems (Lysytsia et al. 2019). Many researches have advocated the need for (and potential of) value creation through inter-organizational collaboration (Le Pennec, Raufflet 2018). The collaborative value is conceptualized as transitory and enduring benefits relative to other costs which are generated by NGOs and business organizations because of the interaction with partners (Austin, Seitanidi 2012a, 2012b; Lyakhov, Gliedt 2017). According to Steijn (2011), who analyzed the effectiveness of partnership results, three forms of value creation can be identified: 1) cost reduction (effectiveness) in the process of achieving results; 2) increasing the desired results (efficiency); 3) creation of new results (innovation). The first two forms are relate to the obtaining of benefits at a lower costs; therefore, the creation of collaborative value can be analyzed on the perspective of costbenefit analysis (Kolk et al. 2008); while the third form reflects the innovative results generated by the partnership, which are particularly important in solving complex problems. Seeking for mentioned effectiveness, efficiency and innovations in the creation of collaborative value the appropriate structures and processes of the governance must be applied in cross-sector partnerships.

Different ways of non-hierarchical coordination between organizations (or horizontal coordination), types of partnerships, forms of their governance, organizational and institutional implications (organizational values, required resources and capabilities, legal framework, and incentives for collaboration) exist (Mendoza 2009). The governance of cross-sector partnerships is defined as a combination of governance of vertical and horizontal 


\section{ENTREPRENEURSHIP AND SUSTAINABILITY ISSUES}

ISSN 2345-0282 (online) http://jssidoi.org/jesi/ 2020 Volume 8 Number 1 (September) http://doi.org/10.9770/jesi.2020.8.1(68)

relationships in a partnership, often without a clear responsible entity (Kooiman 2010). The conceptualization of the governance of cross-sector partnerships is presented through three dimensions: 1) a governance perspective; 2) formal and informal governance mechanisms; 3) stages of cross-sector partnership's processes.

The governance perspective emphasizes that governance in a cross-sector partnership is relational, i.e. it involves at least two participants, it is the dualistic one too - organizational and partnership structures and processes of the governance exist. The specific of the relationality remains in the value creation process where at least two partners must collaborate (Le Ber, Branzei 2010). Cross-sector partnership's governance describes relationships between participants (organizations partners), indicating certain responsibilities of them (Hayes et al. 2011). The governance of such a partnership is a complex process because partnerships are often created without any clear legal form or responsible body; besides, relationships between partners are constantly evolving (Stone et al. 2010).

The governance dimension in cross-sector partnerships is defined as the process of collaborative governance. Partners who engage in a partnership must be able to make decisions together to proceed to the value creation. The scientific literature on the analysis of collaboration and partnership issues describes the governance dimension differently: as the participative decision making (Grudinschi 2014), problem solving (Austin 2000; Crosby, Bryson 2005; Cankar, Petkovšek 2013), shared power arrangements (Crosby, Bryson 2005; Grudinschi 2014). Organizational governance describes relations between individuals and organizations. However, accountability is defined and perceived differently in an organization and partnership (Agranoff, McGuire 2001).

The scientific literature on management and inter-organizational relationships highlights many different tensions that rise from organizational and partnership perspectives through formal and informal structures and processes (Vangen, Huxman 2010; Hayes et al. 2011; Pfisterer, Van Tulder 2020). These tensions reveal why cross-sector partnerships sometimes do not meet participants 'expectations. Tensions are related to the implementation of the partnership and directly affect those who are responsible for governing activities. Participants of the cross-sector partnership need to pay attention on formal and informal mechanisms of the governance (Bryson et al. 2006), the trust level and the level of control. Formal governance mechanisms reflect contractual and authoritative governance, while informal governance mechanisms reflect the role of trust, norms, and solidarity in the crosssector partnership (Hayes et al. 2011, pp. 3). Structures and processes of the multiple governance exist in such partnerships; i. e. participants of the partnership must meet organizational and partnership's expectations. Structures and processes change over the period of the partnership (especially because of existing tensions), therefore, governance mechanisms cannot be static (Alvarez et al. 2010). The choice of governance's approach is influenced by existing relationships and the need to manage them.

There are three main theories in the scientific literature explaining the effectiveness of contractual and relational governance: transaction cost theory, social exchange theory, and relational exchange theory.

The theory of transaction cost explains what the total costs of the partnership are, and what specific costs (transaction costs, operating costs) can be attributed to the partnership (Van Tulder et al. 2016). In this context contractual (formal) governance involves clear structures that define the roles of participants and responsibilities to each other and processes that are implemented through positions of authority (Lynn et al. 2000). Different terms to name the formal governance structures in cross-sector partnerships are used in the scientific literature: formal institutions, formal contracts, formal structures (Hayes et al. 2011). Some authors emphasize formal governance processes such as negotiation, agreement, steering and control (Das, Teng 2000; Crosby, Bryson 2005; Bryson et al. 2006; Forrer et al. 2014). Formal governance reflects contracts and other formal governance and control mechanisms. Contractual governance means the governance of transactions through formal contracts. The main goal is to control actions between partners and to prevent opportunistic behavior through commonly agreed and legally established acceptable behavior. Cullen and Hickman (2001, pp. 1197) emphasize that 


\section{ENTREPRENEURSHIP AND SUSTAINABILITY ISSUES}

ISSN 2345-0282 (online) http://jssidoi.org/jesi/

2020 Volume 8 Number 1 (September)

http://doi.org/10.9770/jesi.2020.8.1(68)

contracts are signed under the assumption that the partner will not fulfill its obligations if it is not controlled. Although contracts and financial obligations are considered as key tools to ensure the security of transactions, implications of the relational governance are increasingly discussed by scholars from different fields.

Informal governance involves structures and processes related to participants' social behavior and informal relationships. In the field of cross-sector relations, relational governance is usually developed based on relational exchange theory and social exchange theory (Benítez-Ávila et al. 2019). Researchers integrated these two theoretical approaches, emphasizing the strong link between established relational norms, the emergence of actual trust, and commitment between partners (Palmatier et al. 2007). Informal (relational) governance is referred to informal institutions, informal structures, informal dimensions (Hayes et al. 2011, pp. 6). Relational governance is based on the basic assumption that any exchange is based on social components. Relational governance is considered as a degree of informal mechanisms and interactions between partners that builds social bonds such as trust, reciprocity, solidarity and norms, which reduce the relational risk and promote the communication and knowledge sharing (Poppo, Zenger 2002; Yang et al. 2011; Benítez-Ávila et al. 2019). Relational governance is based on trust, collaboration, open communication, information sharing, and interdependence (Poppo et al. 2008). Therefore, it can be stated that the relational governance reflects the softer, "human" elements of cross-sector relationships, which take the form of social control and are used to coordinate activities and opportunistic behavior. Two main components of the relational governance are structures and processes. The governance process is considered as a degree of joint actions in the relationship of exchange. The dimension of the relational structure is perceived as the vertical integration of partners, while the processes reflect joint actions.

According to the theory of social exchange, trust arising from socially framed relationships can be an effective tool for governing the cross-sector partnerships (Faems et al. 2008). The theory of relational exchange emphasizes that the trust is the most important component in ensuring social relationships (Palmatier et al. 2007; Xue et al. 2016). The nature of relational relations is not only the economic but also the social one (Caoa, Lumineau 2015). It is focused on the role of social exchange, which is described as voluntary actions of exchange participants motivated by the return they expect to receive from the relationship. Main elements of social exchange are unspecified obligations and reciprocity (Cropanzano, Mithchell 2005; Thacker 2015). Collaborating parties must comply with the rule of reciprocity; otherwise, they may be penalized by social relations. In order to prove their credibility, exchange participants regularly fulfill their obligations and invest in relationships. Connectedness reflects the density of social connections and serves as a management mechanism in the exchange of knowledge (Jaworski, Kohli 1993), promoting the commonality of knowledge and communication. Trust and relational norms are the most common types of relational governance analyzed in the scientific literature (Griffith, Myers 2005). The theory of relational exchange emphasizes relational norms and provides them as another mechanism to enable the analysis of behaviors expected in cross-sector relationships (Palmatier et al. 2007). Relational norms, such as flexibility, information exchange and solidarity, define the comprehensiveness of the relationship and oblige the participants of the exchange to act according to shared relational norms. Acting according to relational norms provides the return with no economic value, including a sense of personal commitment, gratitude, trust, and a shared obligation to maintain collaborative relationships (Cropanzano, Mitchell 2005; Benítez-Ávila et al. 2019). Thus, the trust reflects the belief in a partner's honesty, trustworthiness, goodwill in risky exchange relationships (Das, Teng 2000), while relational norms reflect common expectations that reflect each partner's behavior in cross-sector relationships (Cannon et al. 2000). Both of them may reduce the opportunism; therefore, both are seen as important governance mechanisms. In summary, the relational governance means that: the high level of trust exists between partners; relations are governed using informal norms and procedures; the relationship is flexible while responding to changes.

The relation between contractual and relational governance is usually explained based on the theories mentioned before. Transaction cost theory is used to substantiate the effectiveness of contractual governance, while social exchange and relational exchange theories are used to explain the influence of trust and relational norms on cross- 


\section{ENTREPRENEURSHIP AND SUSTAINABILITY ISSUES}

ISSN 2345-0282 (online) http://jssidoi.org/jesi/

2020 Volume 8 Number 1 (September)

http://doi.org/10.9770/jesi.2020.8.1(68)

sector partnerships. This research is based on the approach that contractual and relational governance are complementary or compensatory mechanisms of the governance of cross-sector partnerships. First, clearly defined terms of a contract can give more confidence to participants of the partnership by promoting the development of relational governance (Poppo, Zenger 2002). Second, contractual relationships clearly define rights, responsibilities and penalties for opportunistic behavior that reduce information asymmetry and create a fair environment among participants, which promotes the development of relational governance (Yang et al. 2011). The contractual governance provides a formal protection for the development of relational governance by formulating and clearly defining roles and responsibilities of each party of the cross-sector partnership. For example, the dimension of contract's control can give signal about a lack of trust and displace the trust in good faith, while the dimension of the contract coordination can reduce misunderstandings and strengthen trust in good faith (Malhotra, Lumineau 2011). Thus, the control dimension forces partners to focus on roles and responsibilities in the partnership, while the coordination dimension creates a structure of common knowledge and promotes the development of trust competencies. Both dimensions can contribute to the value creation.

This research of the collaborative value creation in cross-sector partnerships assumes that the formal (contractual) and informal (relational) governance mechanisms enable the disclosure of joint activities of partners as relational outcomes of cross-sector interactions. Based on this approach, formal and informal governance mechanisms perform functions of knowledge creation and coordination, promoting the collaborative value creation in cross-sector partnerships. Thus, two (organizational and partnership) perspectives of crosssector governance are presented and two interconnected aspects (formal and informal governance mechanisms) are included in this research.

\section{Research methodology}

While analyzing the data, case-oriented theorization has been selected. The value of case-oriented approach is expressed through holistic and particularized causal explanations of the results of a researched case (Piekkari et al. 2009). In case of this research, theorization means "identification of causal processes that generate results in specific contexts" (Piekkari et al. 2009, pp. 571). The context of researched phenomenon is very important when trying to present meaningful explanations. Generalization is presented referring to one situation. Having completed the field research, the collected material is given a theoretical form. Thus, abduction or a deductive way of results' analysis close to it is the most suitable methodological approach of performed qualitative research since the research guidelines are prepared referring to analysis of theoretical conceptions trying to extract the best explanatory reality from them.

Therefore, the research of case study was performed referring to interpretational constructionist approach. We must admit that various realities exist where the existing phenomena can be understood and interpreted differently giving them a subjective meaning i.e. a researcher constructs reality referring to own experience and researcher's attitude to the reality is valid. Qualitative research methods applied in this research are based on such worldview and perception of reality. The research is an explanatory process providing an opportunity to reveal the structure of the phenomenon. Case study provides an opportunity to analyze informative and contextual data and interpreting it to provide conclusions about the researched phenomenon; interpretation has a certain degree of subjectivity and this can be considered as both a disadvantage and an advantage that is related to a particular situation and emotional as well as intellectual information of the researchers.

Value creation based on collaboration in cross-sector partnership is a diverse phenomenon, its examination and analysis can cover different phenomena (organizational, partnership, contextual levels). Considering the complexity and volume of this phenomenon, exploratory and in-depth case study research based on abductive research strategy and systematic coordination has been selected. Trying to determine which aspects of situation can be generalized and which aspects appear due to the specificity of the situation influenced by situational 


\section{ENTREPRENEURSHIP AND SUSTAINABILITY ISSUES}

ISSN 2345-0282 (online) http://jssidoi.org/jesi/

2020 Volume 8 Number 1 (September)

http://doi.org/10.9770/jesi.2020.8.1(68)

environment factors the in-depth case study analysis is performed referring to composed preliminary theoretical tool and developed research instrument. Analytical tool composed on the basis of scientific literature analysis and disclosure study findings combining creation process of collaboration-based value and partnership management dimensions is used.

The research was conducted in Lithuania, as a small developed country, having young traditions of cross-sector partnerships. Organizations having experience in implementation of cross-sector partnership have been selected to analyze the value creation governance processes based on collaboration of empirical units (subjects) in crosssector partnership. Semi-structured interview applied in the research helped to interview people who were able to argumentatively reflect their experience, present insights about collaboration-based value creation in partnership of NGOs and business organizations. Research participants were divided in three groups: NGO, business organizations and NGO and business partnership brokers/mediators. Altogether 22 informants were interviewed: 9 representatives of business organizations (marked IK-V), 9 NGO representatives (marked IK-N) and 4 NGO and business partnership brokers/mediators (marked IK-T). The main requirements for informants and organizations are listed as follows:

a) Business organizations - 1) organizations that have at least one year of partnership experience with NGO; 2) socially responsible business organizations with high reputation;

b) $N G O-1)$ working in the social sphere; 2) organizations that have at least one year of partnership experience with business organization;

c) NGO and business partnership brokers/mediators - 1) persons that provided consultations to NGO and business organizations about partnership issues.

The interview was organized considering the following principles: to present open and clearly formulated questions, to ask one question at a time, nonverbally react to the ideas expressed by the research participants, to encourage the research participant to explain the answer, to ask to present examples, encouraging research participants to present a more comprehensive and more detailed narrative. Interviews were conducted in 2016. Principles of research ethics such as volunteering and confidentiality of interviewees were applied.

\section{Research results and discussion}

The research tried to reveal cross-sector partnership governance practices that enable collaboration-based value creation in the context of NGOs and business organizations partnership. In the context of this article, cross-sector partnership governance is analyzed through two dimensions - at organizations and partnership level and covers two interrelated aspects - formal (contractual) and informal (relational) governance mechanisms. It is assumed that the used governance mechanisms influence partner behavior in cross-sector partnership.

Identification of relational and contractual governance mechanisms. Partnership participants trying to ensure acceptable risk level and governance costs may use different combinations of formal and informal governance mechanisms (Poppo, Zenger 2002). Regardless to the level of formality, cross-sector contracts are treated as a starting point of working together, as a process combining partners for an intended purpose that helps to determine roles and responsibilities of each partner (Rein, Stoott 2009). In formal contracts partnership aim is determined, necessary resources are identified, responsibilities are allocated, the structure of decision making is indicated (Crosby, Bryson 2005). Relational governance reflects softer, "human" elements of cross-sector relationships that appear in the form of social control and are used for coordination of activities and opportunistic behavior. Usually relational governance is related to confidence, mechanisms of social control, commitment, communication, interdependence. 
ENTREPRENEURSHIP AND SUSTAINABILITY ISSUES

ISSN 2345-0282 (online) http://jssidoi.org/jesi/ 2020 Volume 8 Number 1 (September) http://doi.org/10.9770/jesi.2020.8.1(68)

Scientists (Provan, Kenis 2008) state that selection of governance structure influences partnership efficiency. The following governance types are distinguished: a) self-governing governance/self-governance: self-governing structures where decisions are made during regular members' meetings or through distant informal interactions; b) centralized governance: the leading organization makes main decisions and coordinates activities and c) separate unit is formed for partnership administration that coordinates partnership activities (Bryson et al. 2006). While analyzing governance practices of NGOs and business organizations that participated in the research it appeared that cross-sector partnerships are implemented through self-governing governance structures that demand constant communication (see Table 1).

Table 1. Identification of relational governance features and mechanisms

\begin{tabular}{|c|c|c|}
\hline Category & Subcategory & Illustrative statement \\
\hline \multirow[t]{2}{*}{$\begin{array}{l}\text { Governance of } \\
\text { relationships } \\
\text { through } \\
\text { informal } \\
\text { norms and } \\
\text { procedures }\end{array}$} & $\begin{array}{l}\text { Showing constant } \\
\text { attention to the } \\
\text { partner }\end{array}$ & $\begin{array}{l}\text { We (NGO) really try to do our best not to forget and show versatile attention <...> we ask } \\
\text { "how are you?", send information letters with our planned activities (IK-N7); showing } \\
\text { attention or constant "hello-hi" just shows that you are not interesting, I just got from you } \\
\text { what I needed and now do as you wish (IK-N6); I try myself to maintain more or less a kind } \\
\text { of relation with all partners. This relation helps to revive; share information not in } \\
\text { particular about a very narrow initiative or the project, just helps to know each other better } \\
\text { (IK-N5). }\end{array}$ \\
\hline & $\begin{array}{l}\text { Cherishing and } \\
\text { support of personal } \\
\text { relationships } \\
\text { among the partners }\end{array}$ & $\begin{array}{l}\text { A person who works with a partner (business organization) devotes his time to tell about } \\
\text { implemented activities, invites employees to the organization }\langle\ldots\rangle \text { communicates }\langle\ldots\rangle \text { in } \\
\text { principle everything happens because of personal contact (IK-N1); in business organization } \\
\text { people have specific contact with particular people }\langle\ldots\rangle \text { cherishing and support of } \\
\text { relationships help to believe in our activities because they believe in people who work in our } \\
\text { organization (IK-N2); every member of the committee has personal contact with one or } 2-3 \\
\text { NGOs (IK-V-9); }\end{array}$ \\
\hline \multirow[t]{3}{*}{ Trust } & Good reputation & $\begin{array}{l}\text { The contract is made mainly for recovering taxes }\langle\ldots\rangle \text { all other issues are quickly } \\
\text { reconciled. I think that this is because of our } N G O \text { name }<\ldots>\text { partners say "just do, we } \\
\text { trust you" (IK-N1); such western attitude }<\ldots>\text { when we really have trust-based mechanism } \\
\text { that is apparently transferred to our organization in Lithuania (IK-V4). }\end{array}$ \\
\hline & $\begin{array}{l}\text { High level of trust } \\
\text { among the } \\
\text { organizations }\end{array}$ & $\begin{array}{l}\text { Relationships are managed more by trust, because we know them, we know how they work } \\
\text { (IK-V4); we know who "drives" the initiative, I know that they will do, because everything } \\
\text { they promise to do - they do <...> the same "pool" of people (IK-V8). It is easily managed } \\
\text { and easy to control, relationship is quite friendly, in case something happens we would } \\
\text { inform each other that we stop, terminate, consider, and postpone payment (IK-N7). }\end{array}$ \\
\hline & $\begin{array}{l}\text { Open } \\
\text { communication }\end{array}$ & $\begin{array}{l}\text { In big meetings I encourage to be frank with each other: I tell you where the holes are, } \\
\text { where we have to "patch up" the budget and you say what you really need (IK-N5); we need } \\
\text { to speak frankly what we are capable of doing and what not (IK-N2). }\end{array}$ \\
\hline \multirow[t]{2}{*}{$\begin{array}{l}\text { Informal } \\
\text { control } \\
\text { mechanisms }\end{array}$} & $\begin{array}{c}\text { Employee as a } \\
\text { control mechanism }\end{array}$ & $\begin{array}{l}\text { We have a person inside }- \text { a volunteer who can confirm how the funds are used }\langle\ldots\rangle \text { he } \\
\text { ensures proper implementation of activities }(\mathrm{IK}-\mathrm{V} 1) ; \text { the first and most effective control } \\
\text { mechanism is employees who are volunteering }<\ldots>\text { involvement of employees ensures that } \\
\text { funds are being used properly (IK-V3); volunteering of our employees helps to implement } \\
\text { informal control (IK-V3). }\end{array}$ \\
\hline & $\begin{array}{c}\text { Constant } \\
\text { communication }\end{array}$ & $\begin{array}{l}\text { Informal correspondence by e-mails how, for instance, the process is going on }<. .>>\text { I really } \\
\text { want to follow and to hear, because we want to forward that message to the employees, I } \\
\text { want to feel safe that we have done useful work (IK-V2); my personal contact with } \\
\text { organization, a month does not pass without an exchange of e-mails, phone calls (IK-V4). } \\
\text { "Report" is "report", but to my mind, many things are visible mainly through this daily, } \\
\text { weekly, monthly collaboration (IK-V9); constant meetings are really necessary because } \\
\text { employees change and the person that you were communicating with after a half of the year } \\
\text { may not work anymore (IK-N3); besides corresponding we always try to organize live } \\
\text { communication (IK-V6); almost every Friday we have meetings (IK-V9). }\end{array}$ \\
\hline
\end{tabular}

Source: compiled by authors 


\section{ENTREPRENEURSHIP AND SUSTAINABILITY ISSUES}

ISSN 2345-0282 (online) http://jssidoi.org/jesi/ 2020 Volume 8 Number 1 (September) http://doi.org/10.9770/jesi.2020.8.1(68)

While analyzing the features of relational governance applied to the governance of NGO and business organizations partnership, we may state that organizations which participated in the research tend to apply informal forms and procedures in relationship governance. In their opinion, constant attention to the partner and cherishing and support of personal relationships among partners stimulate affection. Referring to scientific literature (Jaworski, Kohli 1993), affection reflects density of relationships, serves as a mechanism during knowledge exchange and stimulates communication. NGO representatives emphasized that: "at the beginning when you do not know a partner or when you as an NGO are not known from the inside, when they do not know how you will fulfill obligations, formal obligations are more important but if the collaboration continues everything is managed by informal communication with organization's representatives, staying in touch, discussing $<\ldots>$ relationship becomes warmer and clearer" (IK-N8). Another important feature of relational governance - trust that reflects faith in partner's honesty, reliability and benevolence in risky exchange relationships. The analysis of research data showed that representatives of business organizations relate trust in NGO to good reputation of this organization: "we have selected those very good partners who are excited about what they do and their reputation speaks for them" (IK-V3). High level of trust between NGO and business organization is related to prior positive collaboration experience and people working in NGO. The representatives of business organizations emphasized that informal control is performed by employees' volunteering. For example, volunteering of employees is related to a possibility to control the suitability of using the funds. Generalizing we may state that during the partnership of NGO and business organization constant social exchanges take place encouraging the feeling of personal commitment, gratitude and general obligation to maintain collaboration-based relationships: "human contact and maintenance of relationships as well as saying "thank you", to my mind, is a significant part of partnership" (IK-N2).

According to Malhotra and Lumineau (2011), contracts can have different impact on relational governance. In this article while analyzing governance of partnership of NGO and business organization, two main functions of contractual governance are distinguished - control and coordination (see Table 2).

During the research it has been identified that NGOs trying to avoid conflict situations with business organizations use contracts as a kind of certain protection: "in the contracts it is clearly indicated what we commit to do and what we will not do <...> a contract is a kind of protection that we will not experience pressure <...> we agree upon the period of time when our name will be used communicating us as a social partner to avoid the situation when I did something once and tell this to everybody for a decade" (IK-N3).

Brokers/mediators of NGO and business organization emphasized that control of business organizations is conditioned by previous negative experience of partnership: "because of not very good experience they [business organizations] control NGO, ask for monthly reports, how much money has been spent, what has been done, why there are deviations from the plan, etc. It is a kind of attitude of financier, control - big control" (IK-T2). We may state that the used control indicates a lack of trust among NGOs and business organizations, i.e. there is a lack of trust in goodwill, therefore, both NGOs and business organizations experience additional time costs trying to constantly control partner. Control function is used trying to avoid partner's opportunistic behavior. 


\section{ENTREPRENEURSHIP AND SUSTAINABILITY ISSUES}

ISSN 2345-0282 (online) http://jssidoi.org/jesi/ 2020 Volume 8 Number 1 (September) http://doi.org/10.9770/jesi.2020.8.1(68)

Table 2. Dimensions of contractual governance

\begin{tabular}{|c|c|c|}
\hline $\begin{array}{c}\text { Table } 2 . \\
\text { Dimensions of } \\
\text { contractual } \\
\text { governance } \\
\text { Category }\end{array}$ & Sub-category & Illustrative statement \\
\hline \multirow[t]{2}{*}{$\begin{array}{l}\text { Functions of } \\
\text { contractual } \\
\text { governance }\end{array}$} & Control dimension & $\begin{array}{l}\text { We sign }\langle\ldots\rangle \text { often partners want that their finances were used for one particular program } \\
\text { rather than the other, therefore, it allows them (business organization) to control where the } \\
\text { money is used (IK-N1); we sign a contract, indicate where exactly the money will be used, } \\
\text { we add the discussed activities as an annex (IK-N5); maybe it's a kind of assurance <... } \\
\text { we sign a contract, discuss conditions, define obligations, put our signatures (IK-N7); } \\
\text { collaboration contracts are always signed and often we have annexes of the contract that } \\
\text { contain activities, obligations of each part, it is indicated who does what (IK-N8). }\end{array}$ \\
\hline & $\begin{array}{c}\text { Coordination } \\
\text { dimension }\end{array}$ & $\begin{array}{l}\text { We define our aims by schedule and time }<\ldots>\text { what the NGO wants to achieve and what } \\
\text { the company. If we speak about publicity, then we must plan PiaR actions, in case of } \\
\text { internal communication, you also plan clearly and precisely how many meetings, which } \\
\text { people participate. Plan is necessary (IK- N5); annual plan is prepared, actions what we } \\
\text { will do are planned }<\ldots>\text { essential moments are discussed what we give and what we get } \\
\text { for this }\langle. .>\text { where are we going, are we doing this purposefully, we discuss time and } \\
\text { deadlines (IK-V5). }\end{array}$ \\
\hline $\begin{array}{c}\text { Formal control } \\
\text { mechanisms }\end{array}$ & Formalized reports & $\begin{array}{l}\text { We ask each partner to prepare a report (IK-V5); one of contract's conditions i.e. after } 6 \\
\text { months a company has to present us a report (IK-V8); one of contract's conditions i.e. after } \\
6 \text { months NGO has to present us a report where they describe what has been implemented, } \\
\text { if the foreseen plans have been achieved (IK-V9). }\end{array}$ \\
\hline
\end{tabular}

Source: compiled by authors

Coordination function is used in NGOs and business organizations partnership in order to coordinate common activities. Malhotra and Lumineau (2011) emphasize that coordination function reduces misunderstandings among partners and promotes trust. The informants emphasized that coordination expressed through formation of annual plans allow to identify if partnership activities are implemented properly.

Institutionalization and governance of cross-sector partnership in a business organization. While performing the research we dissociated from analysis of governance of cross-sector partnership at NGO level, since the selected NGOs have indicated in their mission and aims that partnership with a business organization is one of the strategies of activities implementation. The research results showed that governance of NGO partnership at organizational level depends on managerial abilities of NGO. Institutionalization level of cross-sector partnership in business organization allows identifying business organization's attitude towards social investments and importance of cross-sector partnerships in the context of business organizations. Business organizations having understood strategical importance of social responsibility to business much more often tend to implement partnership with NGOs.

Carroll (1979) states that one of the components of social responsibility - philanthropic responsibility. Completely voluntary activities that depend only upon the decisions of the heads are ascribed to philanthropic or discreet responsibility. In other words, philanthropic responsibility is not provided by the laws or ascribed to ethical behavior of a business organization. Besides, social responsibility becomes a part of business organization's strategy (Vogel 2007). Referring to resource dependence theory philanthropic activities can be considered as means that help business organization to reduce the risk of resource acquisition. It is not a coincidence that philanthropic activities strengthen public image of business organization and interest groups such as government, consumers, suppliers, employees, shareholders and local communities will tend to communicate and provide resources (Backhaus et al. 2002). Therefore, business organizations are encouraged to relate their philanthropic expenses with such spheres that would help to change competitive position of a business organization in a positive way in a long-term perspective. In the context of research we have selected business organizations that implement philanthropic responsibility through partnership with NGOs. We consider the 
ENTREPRENEURSHIP AND SUSTAINABILITY ISSUES

ISSN 2345-0282 (online) http://jssidoi.org/jesi/ 2020 Volume 8 Number 1 (September) http://doi.org/10.9770/jesi.2020.8.1(68)

assumption that collaboration-based value creation depends on institutionalization level of cross-sector partnership in a business organization (see Table 3).

Table 3. Institutionalization and governance of partnership in a business organization

\begin{tabular}{|c|c|c|}
\hline Category & Sub-category & Illustrative statement \\
\hline \multirow{2}{*}{$\begin{array}{l}\text { Cross-sector } \\
\text { partnership as } \\
\text { a strategy of } \\
\text { implementation } \\
\quad \text { of } \\
\text { philanthropic } \\
\text { responsibility }\end{array}$} & $\begin{array}{l}\text { Formation of } \\
\text { partnership } \\
\text { tradition }\end{array}$ & $\begin{array}{l}\text { To my mind, the established tradition helps a lot. At first, maybe it seemed like an order } \\
\text { from above but later it became a tradition }\langle\ldots\rangle \text { people [business organization employees] } \\
\text { are already thinking which NGO to select for partnership, how to get involved (IK-V1); } \\
\text { there are no any additional hours, no payments, nothing, it is already a tradition (IK-V2). }\end{array}$ \\
\hline & $\begin{array}{l}\text { Integration of } \\
\text { philanthropic } \\
\text { responsibility in } \\
\text { business } \\
\text { processes }\end{array}$ & $\begin{array}{l}\text { Earlier it was fashionable to have a person responsible for social responsibility, who had } \\
\text { let's say } 0,25 \text { position, for instance CSR or communication person }<\ldots>\text { now the tradition } \\
\text { changes and it is stated that social responsibility must be integrated in all company's } \\
\text { activities (IK-N5). }\end{array}$ \\
\hline $\begin{array}{l}\text { Formation of } \\
\text { organizational } \\
\text { culture based } \\
\quad \text { on } \\
\text { philanthropic } \\
\text { responsibility }\end{array}$ & $\begin{array}{l}\text { Creation of } \\
\text { employees' } \\
\text { volunteering } \\
\text { program }\end{array}$ & $\begin{array}{l}\text { Globally our company pays very much attention to volunteering }\langle\ldots\rangle \text { an employee is } \\
\text { provided one day for volunteering that is fully paid (IK-V9); it is paid work time, considered } \\
\text { as normal work time <...> transport and all necessary resources are provided (IK-V7); } \\
\text { when this project appeared we were speaking that every employee should volunteer at least } \\
\text { one day <...> this day is paid (IK-V5); it is allowed to volunteer during the work }<\ldots>\text { in } \\
\text { CAC [remark of doctoral student - community action] program it is indicated that having } \\
\text { arranged with the head an employee can volunteer eight hours per year (IK-V3); an } \\
\text { employee can devote at least } 2 \text { days per year to volunteering }\langle\ldots\rangle \text { these days in our } \\
\text { organization are fully paid as working days. If your manager agrees to let you out more } \\
\text { often and understands that it does not interrupt your work process and corresponds to the } \\
\text { strategy of social responsibility of our organization you can volunteer more often (IK-V4). } \\
\text { In our organization volunteering and the so called "CSR" or as we call in our organization } \\
\text { "Citizenship" is completely ingrown in our blood, it is natural for us (IK-V4). }\end{array}$ \\
\hline \multirow[t]{2}{*}{$\begin{array}{l}\text { Creation of } \\
\text { structures of } \\
\text { partnership } \\
\text { governance }\end{array}$} & $\begin{array}{l}\text { Establishment of } \\
\text { informal } \\
\text { partnership } \\
\text { governance } \\
\text { bodies }\end{array}$ & $\begin{array}{l}\text { In our company there is such practice as "Charity" committee. It means that employees } \\
\text { gather in groups of 6-7 people who want to get involved in partnership with NGOs during } \\
\text { the year (IK-V1); we have two committees <...> one of them is looking for NGOs that we } \\
\text { could support and the other one is responsible for volunteering of employees (IK-V9); in } \\
\text { Vilnius there is such informal council where every activity has its own coordinator, I am the } \\
\text { coordinator of these coordinators (IK-V3). }\end{array}$ \\
\hline & $\begin{array}{l}\text { The process of } \\
\text { partnership } \\
\text { governance is } \\
\text { focused on } \\
\text { coordinators of } \\
\text { social } \\
\text { responsibility }\end{array}$ & $\begin{array}{l}\text { My direct duties - coordinator for social responsibility projects }<\ldots>\text { I coordinate all issues } \\
\text { related to NGOs, volunteering, various external projects (IK-V4); me and my several } \\
\text { colleagues are coordinators of initiatives, ambassadors of CSR initiatives in the company. } \\
\text { We regularly meet, discuss, create a plan and respectively communicate and plan projects } \\
\text { with NGOs (IK-V7). }\end{array}$ \\
\hline \multirow{3}{*}{$\begin{array}{l}\text { Creation of } \\
\text { partnership } \\
\text { financing } \\
\text { system }\end{array}$} & Program funding & $\begin{array}{l}\text { Every year the company allocates a certain budget for the development of the program }\langle\ldots\rangle \\
\text { departments that participate in the program may apply and get money for implementation of } \\
\text { activities with NGOs (IK-V3). }\end{array}$ \\
\hline & $\begin{array}{l}\text { Formation of a } \\
\text { separate budget }\end{array}$ & $\begin{array}{l}\text { Planning the budget for the next year in advance we always think what activities we will } \\
\text { implement being partners with NGOs (IK-V6). }\end{array}$ \\
\hline & $\begin{array}{l}\text { Matched } \\
\text { fundraising }\end{array}$ & $\begin{array}{l}\text { We have a "matched fundraising" option, our employees get an opportunity to organize } \\
\text { specific activities and in such way collect money for a particular NGO. If everything is } \\
\text { organized following the determined rules, the organization doubles collected amount <...> } \\
\text { each of us has to put our contribution to make the support happen (IK-V3); the company } \\
\text { adds as much as we collect so the amount is double (IK-V3); if each of us gives one euro, } \\
\text { our parent company triples the amount }<\ldots>\text { this is our main funding (IK-V9). }\end{array}$ \\
\hline $\begin{array}{l}\text { Support of } \\
\text { management } \\
\text { staff }\end{array}$ & $\begin{array}{l}\text { Head's positive } \\
\text { provisions and } \\
\text { decision to } \\
\text { cooperate }\end{array}$ & $\begin{array}{l}\text { To my mind, it depends on head's maturity }<\ldots>\text { earlier there were more companies where } \\
\text { the head was authoritarian or dictator who just said I will or I won't support; now there are } \\
\text { more and more companies that consider practice from western Europe }\langle\ldots\rangle \text { they discuss } \\
\text { what organizations to support, what to do, which direction to select (IK-N5); a game } \\
\text { (remark by doctoral student - partnership) is built on the heads, if the heads are positive and } \\
\text { understand we will cooperate in any case, if due to some reasons they think differently, the } \\
\text { arguments will not help (IK-N6); since the head was Danish <...> very involved in }\end{array}$ \\
\hline
\end{tabular}


ENTREPRENEURSHIP AND SUSTAINABILITY ISSUES

ISSN 2345-0282 (online) http://jssidoi.org/jesi/

2020 Volume 8 Number 1 (September)

http://doi.org/10.9770/jesi.2020.8.1(68)

\begin{tabular}{|l|l|l|}
\hline Category & Sub-category & \multicolumn{1}{c|}{ Illustrative statement } \\
\hline & & $\begin{array}{l}\text { partnerships with NGOs abroad, we wanted to share this good experience also in Lithuania } \\
\text { (IK-V2). }\end{array}$ \\
\hline
\end{tabular}

Source: compiled by authors

During the research we have noticed that the guidelines of social responsibility of the companies that participated in the research are drawn by the parent companies, so business organizations of foreign capital acting in Lithuania adapt them to Lithuanian context: "the guidelines of social responsibilities are created at ", high level", and in the Baltic States we adapt them and transfer into practical level" (IK-V7). Representatives of NGO emphasized that continuity of partnership depends on head's attitude to partnerships with NGOs, "from the level of integration of partnership into governance processes of business organization, volunteering, and integration of donation culture into the activities of business organization: "in our company partnership index is one of the most important business indexes, so called key performance indicators" <...> every year we decide what kind of employees' involvement we want" (IK-V3). In all business organizations that participated in the research partnership governance structures and financing systems are created.

\section{Conclusions}

Analyzed and generalized theoretical provisions of conception of relational governance and resources-based approach allow to state that cross-sector partnership is an emerging process covering uncertainty conditioned by the context, type of process, and relationships with a partner and results; it is a manifold process the development of which depends on partnership characteristics. Stages and their characteristics determine the type of relationships, enable partners to identify necessary level of responsibility that helps to achieve intended aims.

It has been revealed that time dimension in the analysis of cross-sector partnership is used trying to distinguish static partnership characteristics and process-based approach enables to reveal the process of cross-sector partnership governance that influences the creation of collaboration-based value. Trying to reveal deeper the process of formation and implementation of cross-sector partnership it is necessary to overstep existing standardized stages of partnership formation and implementation and to distinguish micro processes that form separate stages of cross-sector partnership.

Referring to the findings of qualitative research it has been determined that value creation based on collaboration in cross-sector partnership is influenced by partnership context that consists of macro and mezzo stimulating and limiting factors, characteristics of $N G O$ and business organization, selection of a proper partner as well as formal and informal mechanisms of partnership governance.

Having generalized research data it has been identified that cross-sector partnerships are implemented through self-governing governance structures that require constant communication. Analyzing the features of relational governance applied in management of NGOs and business organizations partnerships we may state that organizations participating in the research tend to apply informal forms and procedures for relationship management. During the research it has been identified that NGOs trying to avoid conflicts with business organizations use contracts as a kind of protection.

Although during the research the brokers/mediators of NGO and business partnership have been interviewed as persons able to properly reflect the experiences of NGO and business partnership formation and implementation, their role and influence on collaboration-based value creation in cross-sector partnership have not been revealed. Therefore, it is recommended to perform further research determining role and functions of brokers/mediators of NGO and business partnership in collaboration-based value creation in cross-sector partnership. 


\section{ENTREPRENEURSHIP AND SUSTAINABILITY ISSUES}

ISSN 2345-0282 (online) http://jssidoi.org/jesi/ 2020 Volume 8 Number 1 (September)

http://doi.org/10.9770/jesi.2020.8.1(68)

Trying to determine context influence on the development of cross-sector partnership, disclosure of governance mechanisms in further research perspective it would be appropriate to perform comparative analysis of other European countries that have similar level of economic and social development.

\section{References}

Agranoff, R.; \& Mcguire, M. 2001. Big questions in public network management research, Journal of Public Administration Research and Theory 11: 295-326. https://doi.org/10.1093/oxfordjournals.jpart.a003504

Alvarez, G.; Pilbeam, C.; \& Wilding, R. 2010. Nestle Nespresso AAA sustainable quality program: an investigation into the governance dynamics in a multi-stakeholder supply chain network, Supply Chain Management: An International Journal 15: 165-182. https://doi.org/10.1108/13598541011028769

Austin, J. E. 2000. Strategic alliances between nonprofits and businesses, Nonprofit \& Voluntary Sector Quarterly 29(1): 69-97. https://doi.org/10.1177/0899764012450777

Austin, J. E. 2010. The collaboration challenge: How nonprofits and businesses succeed through strategic alliances. San Francisco: John Wiley \& Sons.

Austin, J. E.; \& Seitanidi, M. M. 2012a. Collaborative value creation. A review of partnering between nonprofits and businesses: Part I. Value creation spectrum and collaboration stages, Nonprofit and Voluntary Sector Quarterly 41(5): 726-758. https://doi.org/10.1177/0899764012450777

Austin, J. E.; \& Seitanidi, M. M. 2012b. Collaborative value creation. A review of partnering between nonprofits and businesses. Part 2: Partnership processes and outcomes, Nonprofit and Voluntary Sector Quarterly 41(6): 929-968. https://doi.org/10.1177/0899764012454685

Backhaus, K. B.; Stone, B. A.; \& Heiner, K. 2002. Exploring the relationship between corporate social performance and employer attractiveness, Business Society 41: 292-318. https://doi.org/10.1177/0007650302041003003

Bano, M. 2019. Partnerships and the good-governance agenda: Improving service delivery through state-NGO collaborations, VOLUNTAS: International Journal of Voluntary and Nonprofit Organizations 30(6), 1270-1283. https://doi.org/10.1007/s11266-017-9937-y

Benítez-Ávila, C.; Hartmann, A.; \& Dewulf, G. 2019. Contractual and relational governance as positioned-practices in ongoing publicprivate partnership projects, Project Management Journal 50(6): 716-733. https://doi.org/10.1177/8756972819848224

Branzei, O.; \& Le Ber, M. J. 2014. Theory-method interfaces in cross-sector partnership research, in Seitanidi, M. M. \& Crane, A. (Eds.). Social partnerships and responsible business. A research handbook. London: Routledge, 229-266.

Bryson, J. M.; Crosby, B. C.; \& Stone, M. M. 2006. The design and implementation of cross-sector collaborations: Propositions from the literature, Public Administration Review 66 (1): 44-55. https://doi.org/10.1111/j.1540-6210.2006.00665.x

Cankar, S. S.; \& Petkovšek, V. 2013. Private and public sector innovation and the importance of cross-sector collaboration, Journal of Applied Business Research 29(6), 1597-1606. https://doi.org/10.19030/jabr.v29i6.8197

Cannon, J. P.; Achrol, R.S.; \& Gundlach, G.T. 2000. Contracts, norms, and plural form governance, Journal of the Academy of Marketing Science 28(2): 180-194. https://doi.org/10.1177/0092070300282001

Caoa, Zh.; \& Lumineau, F. 2015. Revisiting the interplay between contractual and relational governance: A qualitative and meta-analytic investigation, Journal of Operations Management 33-34: 15-42. https://doi.org/10.1016/j.jom.2014.09.009

Carroll, A. B. 1979. A three-dimensional conceptual model of corporate performance, Academy of Management Review 4(4): 497-505. https://doi.org/10.5465/amr.1979.4498296

Chesbrough, H.; Lettl, C.; \& Ritter, T. 2018. Value creation and value capture in open innovation, Journal of Product Innovation Management 35(6): 930-938. https://doi.org/10.1111/jpim.12471 


\section{ENTREPRENEURSHIP AND SUSTAINABILITY ISSUES}

ISSN 2345-0282 (online) http://jssidoi.org/jesi/ 2020 Volume 8 Number 1 (September) http://doi.org/10.9770/jesi.2020.8.1(68)

Clarke, A.; \& Fuller, M. 2010. Collaborative strategic management: strategy formulation and implementation by multi-organizational cross-sector social partnerships, Journal of BusinessEthics 94(Supplement 1): 85-101. https://doi.org/10.1007/s10551-011-0781-5

Cropanzano, R.; \& Mitchell, M. S. 2005. Social exchange theory: an interdisciplinary review, Journal of Management 31: 874-900. https://doi.org/10.1177/0149206305279602

Crosby, B. C.; \& Bryson, J. M. 2005. A leadership framework for cross-sector collaboration, Public Management Review 7(2): 177-201. https://doi.org/10.1080/14719030500090519

Cullen, P. A.; \& Hickman, R. 2001. Contracting and economic alliances in the aerospace sector: Do formal contract arrangements support or impede efficient supply chain relationships?, Technovation 21 : 525-533. https://doi.org/10.1016/S0166-4972(00)00073-0

Das, T. K.; \& Teng, B. S. 2000. A resource-based theory of strategic alliances, Journal of Management 26: 31-61. https://doi.org/10.1016/S0149-2063(99)00037-9

Demir, A.; \& Budur, T. 2019. Roles of leadership styles in corporate social responsibility to non-governmental organizations (NGOs), International Journal of Social Sciences \& Educational Studies 5(4): 174-183. https://doi.org/10.23918/ijsses.v5i4p174

Dentoni, D.; Bitzer, V.; \& Pascucci, S. 2016. Cross-sector partnerships and the co-creation of dynamic capabilities for stakeholder orientation, Journal of Business Ethics 135: 35-53. https://doi.org/10.1007/s10551-015-2728-8

Faems, D.; Janssens, M.; Madhok, A.; \& Van Looy, B. 2008. Toward an integrative perspective on alliance governance: connecting contract design, trust dynamics, and contract application, Academy of Management Journal 51(6): 1053-1078. https://doi.org/10.5465/amj.2008.35732527

Forrer, J.; Kee, J. J.; \& Boyer, E. 2014. Governing cross-sector collaboration. San Francisco: John Wiley \& Sons.

Getha-Taylor, H. 2012. Cross-sector understanding and trust, Public Performance \& Management Review 36(2): 216-229. https://doi.org/10.2753/PMR1530-9576360203

Griffith, D.; \& Myers, M. 2005. The performance implications of strategic fit of relational norm governance strategies in global supply chain relationships, Journal of International Business Studies 36(3): 254-269. https://doi.org/10.1057/palgrave.jibs.8400131

Grudinschi, D. 2014. Strategic management of value networks: how to create value in cross-sector collaboration and partnerships. Doctoral dissertation. Lappeenranta, Finland: Lappeenranta University of Technology. Retrieved from https://www.semanticscholar.org/paper/Strategic-management-of-value-networks\%3A-how-to-inGrudinschi/dd7bf710b69bf2f828d7d836dbb999c9937c6b56

Hankammer, S.; \& Kleer, R. 2018. Degrowth and collaborative value creation: Reflections on concepts and technologies, Journal of Cleaner Production 197: 1711-1718. https://doi.org/10.1016/j.jclepro.2017.03.046

Hayes, J. P.; Cornforth, Ch.; \& Vangen, S. 2011. Governance in cross-sector partnershipsinvolving third sector organisations. 25th British Academy of Management Conference, September 13-15. Birmingham. Retvieved from http://oro.open.ac.uk/31910/2/Tensions_and_governance.pdf

Herlin, H. 2015. Better safe than sorry: Nonprofit organizational legitimacy and cross-sector partnerships, Business \& Society 54(6): 822858. https://doi.org/10.1177/0007650312472609

Jamali, D.; \& Keshishian, T. 2009. Uneasy alliances: Lessons learned from partnerships between businesses and NGOs in the context of CSR, Journal of Business Ethics 84: 277-295. https://doi.org/10.1007/s10551-008-9708-1

Jaworski, B. J.; \& Kohli, A. K. 1993. Market orientation: antecedents and consequences, Journal of Marketing 57(3): 53-70. https://doi.org/10.1177/002224299305700304

Kelman, S.; Hong, S.; \& Turbitt, I. 2013. Are there managerial practices associated with the outcomes of an interagency service delivery collaboration? Evidence from British crime and disorder reduction partnerships, Journal of Public Administration Research and Theory 23(3): 609-630. https://doi.org/10.1093/jopart/mus038

Kolk, A.; Van Tulder, R.; \& Kostwinder, E. 2008. Business and partnerships for development, European Management Journal 26(4): 262273. https://doi.org/10.1016/j.emj.2008.01.007 


\section{ENTREPRENEURSHIP AND SUSTAINABILITY ISSUES}

ISSN 2345-0282 (online) http://jssidoi.org/jesi/ 2020 Volume 8 Number 1 (September)

http://doi.org/10.9770/jesi.2020.8.1(68)

Kooiman, J. 2010. Governance and governability, in Osborne, S. P. (Ed.). The new public governance? Emerging perspectives on the theory and practice of public governance. London: Routledge, 88-102.

Le Ber, M. J.; \& Branzei, O. 2010. Value frame fusion in cross sector interactions, Journal of Business Ethics 94: 163-195. https://doi.org/10.1007/s10551-011-0785-1

Le Pennec, M.; \& Raufflet, E. 2018. Value creation in inter-organizational collaboration: An empirical study, Journal of Business Ethics 148(4): 817-834. https://doi.org/10.1007/s10551-015-3012-7

Lee, L. 2011. Business-community partnerships: Understanding the nature of partnership, Corporate Governance 11(1): 29-40. https://doi.org/10.1108/14720701111108826

Lyakhov, A.; \& Gliedt, T. 2017. Understanding collaborative value creation by environmental nonprofit and renewable energy business partnerships, VOLUNTAS: International Journal of Voluntary and Nonprofit Organizations 28(4): 1448-1472. https://doi.org/10.1007/s11266-016-9691-6

Lynn, L. E.; Heinrich, C. J.; \& Hill, C. J. 2000. Studying governance and public management: Challenges and prospects, Journal of Public Administration Research and Theory 10: 233-262. https://doi.org/10.1093/oxfordjournals.jpart.a024269

Lysytsia, N.; Martynenko, M.; Bielikova, N.; Gron, O.; \& Us, M. 2019. Directions of social partnership of employers and universities in the sphere of economic education in Ukraine, Entrepreneurship and Sustainability Issues 7(1): 336-352. http://doi.org/10.9770/jesi.2019.7.1(25)

Malhotra, D.; \& Lumineau, F. 2011. Trust and collaboration in the aftermath of conflict: The effects of contract structure, Academy of Management Journal 54(5): 981-998. https://doi.org/10.5465/amj.2009.0683

Maucuer, R.; \& Renaud, A. 2019. Company's business models and NGOs: Inputs from the partnerships portfolio, International Management 23(3): 172-185. Retrieved from https://hal.archives-ouvertes.fr/hal-02403835

Mendoza, X. 2009. Relational strategies for bridging and promoting cross-sector collaboration, International Journal of Integrated Care, 9(5). http://doi.org/10.5334/ijic.356

Palmatier, R.; Dant, R. P.; \& Grewal, D. 2007. A comparative longitudinal analysis of theoretical perspectives of interorganizational relationship performance, Journal of marketing 71 (4): 172-194. https://doi.org/10.1509/jmkg.71.4.172

Pfisterer, S.; \& Van Tulder, R. 2020. Governing partnerships for development in post-conflict settings: Evidence from a longitudinal case study in Colombia, Business Ethics: A European Review 00: 1-17. https://doi.org/10.1111/beer.12278

Piekkari, R.; Welch, C.; \& Paavilainen, E. 2009. The case study as disciplinary convention: Evidence from international business journals, Organizational Research Methods 12(3): 567-598. https://doi.org/10.1177/1094428108319905

Poppo, L.; \& Zenger, T. 2002. Do formal contracts and relational governance function as substitutes or complements?, Strategic Management Journal 23(8): 707-725. https://doi.org/10.1002/smj.249

Poppo, L.; Zhou, K. Z.; \& Zenger, T. 2008. Examining the conditional limits of relational governance: Specialized assets, performance ambiguity, and long-standing ties, Journal of Management Studies 45: 1195-1216. https://doi.org/10.1111/j.1467-6486.2008.00779.x

Porter, M. E.; \& Kramer, M. R. 2011. The big idea. Creating shared value. How to reinvent capitalism-and unleash a wave of innovation and growth, Harvard Business Review, 89(1-2): 1-17. Retrieved from http://www.coherence360.com/praxis/wpcontent/uploads/2015/08/Michael_Porter_Creating_Shared_Value.pdf

Provan, K. G.; \& Kenis, P. 2008. Modes of network governance: Structure, management, and effectiveness, Journal of Public Administration Research and Theory 18(2): 229-252. https://doi.org/10.1093/jopart/mum015

Rein, M.; \& Stott, L. 2009. Working together: Critical perspectives on six cross-sector partnerships in Southern Africa, Journal of Business Ethics 90: 79-89. https://doi.org/10.1007/s10551-008-9915-9

Rivera-Santos, M.; Rufin, C.; \& Kolk, A. 2012. Bridging the institutional divide: Partnerships in subsistence markets, Journal of Business Research 65(12): 1721-1727. https://doi.org/10.1016/j.jbusres.2012.02.013 


\section{ENTREPRENEURSHIP AND SUSTAINABILITY ISSUES}

ISSN 2345-0282 (online) http://jssidoi.org/jesi/ 2020 Volume 8 Number 1 (September) http://doi.org/10.9770/jesi.2020.8.1(68)

Sakarya, S.; Bodur, M.; Yildirim-Öktem, Ö.; \& Selekler-Göksen, N. 2012. Social alliances: Business and social enterprise collaboration for social transformation, Journal of Business Research 65(12): 1710-1720. https://doi.org/10.1016/j.jbusres.2012.02.012

Schuster, T.; \& Holtbrügge, D. 2014. Benefits of cross-sector partnerships in markets at the base of the pyramid, Business Strategy and the Environment 23(3): 188-203. https://doi.org/10.1002/bse.1780

Seitanidi, M. M. 2008. Adaptive responsibilities: Non-linear interactions in cross sectoral social partnerships, Emergence: Complexity \& Organization 10(3): 51-64. Retrieved from https://ssrn.com/abstract=1554883

Seitanidi, M. M. 2010. The politics of partnerships: A critical examination of nonprofit-business partnerships. London, New York: Springer Science+Business Media.

Seitanidi, M. M.; \& Crane, A. 2009. Implementing CSR through partnerships: Understanding the selection, design and institutionalisation of nonprofit-business partnerships, Journal of Business Ethics 85(2): 251-477. https://doi.org/10.1007/s10551-008-9743-y

Seitanidi, M.; \& Ryan, A. 2007. A critical review of forms of corporate community involvement: from philanthropy to partnerships, International Journal of Nonprofit \& Voluntary Sector Marketing 12(3): 247-266. https://doi.org/10.1002/nvsm.306

Selsky, J. W.; \& Parker, B. 2005. Cross-sector partnerships to address social issues: Challenges to theory and practice, Journal of Management 31(6): 849-873. https://doi.org/10.1177/0149206305279601

Selsky, J. W.; \& Parker, B. 2010. Platforms for cross-sector social partnerships: Prospective sensemaking devices for social benefit, Journal of Business Ethics 94(1): 21-37. https://doi.org/10.1007/s10551-011-0776-2

Southby, K.; \& Gamsu, M. 2018. Factors affecting general practice collaboration with voluntary and community sector organizations, Health \& Social Care in the Community 26(3): e360-e369. https://doi.org/10.1111/hsc.12538

Sroka, W.; \& Szántó, R. 2018. Corporate social responsibility and business ethics in controversial sectors: Analysis of research results, Journal of Entrepreneurship, Management and Innovation 14(3): 111-126. https://doi.org/10.7341/20181435

Steijn, B.; Klijn, E. H.; \& Edelenbos, J. 2011. Public-private partnerships: Added value by organizational form or management?, Public Administration 89: 1235-1252. https://doi.org/10.1111/j.1467-9299.2010.01877.x

Stejskal, J.; Mikušová Meričková, B.; \& Prokop, V. 2016. The cooperation between enterprises: significant part of the innovation process: a case study of the czech machinery industry, Ekonomika a management XIX(3): 110-122. https://doi.org/10.15240/tul/001/2016-3-008

Stone, M. M.; Crosby, B. C.; \& Bryson, J. M. 2010. Governing public-nonprofit collaborations understanding their complexity and the implications for research, Voluntary Sector Review 1: 309-334. https://doi.org/10.1332/204080510X538310

Teegen, H.; Doh, J. P.; \& Vachani, S. 2004. The importance of nongovernmental organizations (NGOs) in global governance and value creation: An international business research agenda, Journal of International Business Studies 35: 463-483. https://doi.org/10.1057/palgrave.jibs.8400112

Thacker, R. A. 2015. The application of social exchange to commitment bonds of pro-union employees: Cognitive calculations of reciprocity, Human Resource Management Review 25(3): 287-297. https://doi.org/10.1016/j.hrmr.2014.10.001

Van Tulder, R.; \& Keen, N. 2018. Capturing collaborative challenges: Designing complexity-sensitive theories of change for cross-sector partnerships, Journal of Business Ethics 150(2): 315-332. https://doi.org/10.1007/s10551-018-3857-7

Van Tulder, R.; Seitanidi, M. M.; Crane, A.; \& Brammer, S. 2016. Enhancing the impact of cross-sector partnerships, Journal of Business Ethics 135(1), 1-17. https://doi.org/10.1007/s10551-015-2756-4

Vangen, S.; \& Huxham, C. 2010. Introducing the theory of collaborative advantage, in Osborne, S. P. (Ed.). The new public governance? Emerging perspectives on the theory and practice of public governance. London: Routledge, 163-184.

Vogel, D. 2007. The market for virtue: The potential and limits of corporate social responsibility. Washington, D. C.: Brookings Institution Press. 


\section{ENTREPRENEURSHIP AND SUSTAINABILITY ISSUES}

ISSN 2345-0282 (online) http://jssidoi.org/jesi/ 2020 Volume 8 Number 1 (September) http://doi.org/10.9770/jesi.2020.8.1(68)

Wymer, W. W.; \& Samu, S. 2009. The influence of cause marketing associations on product and cause brand value, International Journal of Nonprofit and Voluntary Sector Marketing 14: 1-20. https://doi.org/10.1002/nvsm.348

Xue, J.; Yuan, H.; \& Shi, B. 2016. Impact of contextual variables on effectiveness of partnership governance mechanisms in megaprojects: Case of Guanxi. Journal of Management in Engineering 33(1): 04016034. https://doi.org/10.1061/(ASCE)ME.1943-5479.0000476

Yang, Z.; Zhou, C.; \& Jiang, L. 2011. When do formal control and trust matter? A context-based analysis of the effects on marketing channel relationships in China. Industrial Marketing Management 40(1): 86-96. https://doi.org/10.1016/j.indmarman.2010.09.013

Yaziji, M.; \& Doh, J. 2009. NGOs and corporations: conflict and collaboration. New York: Cambridge University Press.

Dr Jurgita JONIŠKIENĖ works as the lecturer in the Institute of Regional Development, Šiauliai University, Šiauliai, Lithuania. Research interests: NGO management, cross-sector interactions, civil society, NGO and public institutions partnerships.

ORCID ID: orcid.org/0000-0001-7683-1941

Dr Diana ŠAPARNIENE works as the professor in the University of Latvia, Riga, Latvia and the professor in the Department of Sports, Recreation and Tourism of Klaipėda University, Klaipeda, Lithuania. Research interests: organisation management in a changing society, social research methodology, Good Governance at local self-government.

ORCID ID: orcid.org/0000-0002-0597-3309

Dr Vita JUKNEVIČIENÉ works as the associate professor and a research fellow in the Institute of Regional Development, Šiauliai University, Śiauliai, Lithuania. She is the chairperson of the Coordination Committee of the Researchers' Excellence Network (RENET), coordinated by Šiauliai University. Research interests: innovation management, public-private partnerships, Good Governance at local selfgovernment.

ORCID ID: orcid.org/0000-0001-5910-3010

Dr Tadas LIMBA works as the professor and a research fellow in the Faculty of Public Management and Business, Mykolas Romeris University, Vilnius, Lithuania. Research interests: Cybersecurity Management, Digital Content, IT Law, Data Protection, New Public Management, E-Government, modernisation of public sector.

ORCID ID: orcid.org/0000-0003-2330-8684

Dr Iveta REINHOLDE works as the professor and a Head of Political Science Department in the University of Latvia, Riga, Latvia. Research interests: public policy and administration, legitimacy and authority, Good Governance, management of the public sector.

ORCID ID: orcid.org//0000-0001-9052-4227

Make your research more visible, join the Twitter account of ENTREPRENEURSHIP AND SUSTAINABILITY ISSUES: @Entrepr69728810

Copyright (C) 2020 by author(s) and VsI Entrepreneurship and Sustainability Center

This work is licensed under the Creative Commons Attribution International License (CC BY).

http://creativecommons.org/licenses/by/4.0/

(c) (†) Open Access 